\title{
Dictynna
}

Dictynna

Revue de poétique latine

14 | 2017

Varia

\section{How Prudentian is the Aeneid?}

Philip Hardie

\section{(2) OpenEdition}

\section{Journals}

Electronic version

URL: http://journals.openedition.org/dictynna/1431

DOI: 10.4000/dictynna. 1431

ISSN: 1765-3142

\section{Electronic reference}

Philip Hardie, «How Prudentian is the Aeneid? », Dictynna [Online], 14 | 2017, Online since 20 November 2017, connection on 10 September 2020. URL : http://journals.openedition.org/dictynna/1431 ; DOI : https://doi.org/10.4000/dictynna.1431

This text was automatically generated on 10 September 2020 .

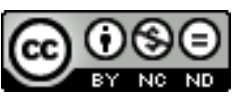

Les contenus des la revue Dictynna sont mis à disposition selon les termes de la Licence Creative Commons Attribution - Pas d'Utilisation Commerciale - Pas de Modification 4.0 International. 


\title{
How Prudentian is the Aeneid?
}

\author{
Philip Hardie
}

\section{AUTHOR'S NOTE}

I am grateful to the thoughtful comments of the anonymous readers, which have helped me to rethink some of the points in this paper. It is a pleasure to dedicate a discussion of the self-consciousness of a late Latin text to Alain Deremetz, who has done so much to promote our awareness of the sophisticated knowingness of Latin poetry.

1 Prudentius' Psychomachia is often taken to mark a new departure in the history of epic. For the first time the cast-list of an epic narrative consists almost entirely of personifications, characters who have no reality other than as allegorical embodiments of mental states or moral abstractions. The Psychomachia was very popular in the Middle Ages, as witnessed by the large number of manuscripts, and by its enormous influence on both medieval literature and visual arts. So, here is a work that seems to mark a watershed between the poetics of classical antiquity and the poetics of the Middle Ages.

2 At the same time it has always been clear that the Psychomachia is a highly Virgilian work, which in itself no doubt a factor in its popularity in succeeding centuries, in which Virgil, and the Aeneid above all, were always central to education. ${ }^{1}$ Prudentius calls attention to the model of the Aeneid in the first line (after the iambic praefatio), one of the poem's closest adaptations of a Virgilian line:

Christe, graues hominum semper miserate labores ...

Christ, who has always taken pity on the heavy labours of men ...

3 This slightly varies the first line of Aeneas' prayer to Apollo in his interview with the Sibyl at Cumae, Aeneid 6.56: 2

Phoebe, grauis Troiae semper miserate labores ...

Apollo, who has always taken pity on the heavy labours of Troy ...

Christian Gnilka, among others, has analysed the continuities and contrasts with the Virgilian plot that emerge from Prudentius' replacement of two words in the Virgilian 
line, Phoebe by Christe, and Troiae by hominum. ${ }^{3}$ Further observations on the Kontrastimitation operative here may be added. After invoking Christ, Prudentius immediately asserts the orthodox oneness of the Son with the Father, 2-4 qui patria uirtute cluis propriaque, sed una, I (unum namque Deum colimus de nomine utroque, I non tamen et solum, quia tu Deus ex Patre, Christe) 'you who are renowned for your father's power and for your own, but one power (for it is one God that we worship under two names, but not at the same time a God on his own, since you, o Christ, are God born of the Father).' The Christian God is truly one, A-pollo, 'not many', whereas Apollo is only one of many gods (and Aeneas concedes that point ostentatiously when he goes on to invoke, Aen. 6.64 dique deaeque omnes). And does non ... solum hint that Christ is not to be identified with the Sun, Sol (for all that figuratively he is the Christian sun)? labores at the start of an epic will put us in mind of Virgil's programmatic use of labores at the start of the Aeneid, 1.10 tot adire labores. The initial placing of miserate hints at Virgil's address to another 'god', Caesar Octavian, at the beginning of the Georgics, 1.41 ignarosque uiae mecum miseratus agrestis 'taking pity with me on the countryfolk who do not know the way'. Recollection of that opening alerts the reader to the strong presence of didactic elements in the Psychomachia (closely related to Prudentius' more overtly didactic poems, Apotheosis and Hamartigenia). ${ }^{4}$ The replacement of Troiae by hominum perhaps hints at an allegorization of the woes of Virgil's Trojans as the woes of all mankind after the Fall. Finally, Aeneas' prayer to Apollo and all the gods, and to the Sibyl, to be granted an ending to the wanderings and toils of the Trojans and to be allowed to settle in their promised land of Latium, is followed by the vow of a temple to Apollo and Diana, which finds its counterpart in the Temple of Sapientia built by the Virtues after their successful defeat of the Vices at the end of the Psychomachia. For Virgil's reader, Aeneas' vow of a temple in Latium foreshadows the Palatine Temple of Apollo dedicated in $29 \mathrm{BC}$ by Augustus, and which appears at the climax of Roman history in the ecphrasis of the Shield of Aeneas (Aen. 8.720-2). Prudentius overbids the Virgilian sequence of temples of Apollo (that founded at Cumae by Daedalus, in the legendary past, and those to be founded in the future on Latin soil and in Rome, by Aeneas and Augustus) with a temple that marks the end of a Christian history, a temple which alludes to a sequence of biblical temples: the Temple of Solomon (1 Kings 6), the vision of a temple at Ezekiel 40-7, and finally the celestial Jerusalem of Revelation.

5 In this paper I focus on the feature of the Psychomachia that is supposed to mark a decisive break from the tradition of classical epic, the fact that it is an allegorical epic, and ask how Virgilian, in reality, its allegorical themes and procedures may be. As a study of intertextuality, the paper also poses the question of whether reading the Psychomachia through the Aeneid also brings yields in terms of reading the Aeneid through the Psychomachia. Does attention to Prudentius' allusive practice sensitize us to the allegorical qualities of the Aeneid, qualities that we might otherwise be inclined to overlook or discount? How Prudentian is the Aeneid? I should confess that this kind of approach has points in common with my first book, Virgil's Aeneid: cosmos and imperium (Oxford 1986), which had as a subtext, not stated overtly, that medieval and Renaissance allegorical readings of the Aeneid might be as worthy of a modern reader's attention as the models of reading dominant in most nineteenth- and twentiethcentury interpretation. As a return to my beginnings this is, I suppose, a kind of retour sur soi. 
6 The Psychomachia is characterized by a range of different kinds of allegorical and exegetical practices: typology (the prefiguration of New Testament events and persons in the events and persons of the old Testament), eschatological foreshadowing, a spiritual exegesis that is fundamentally Pauline, and the moral lessons to be drawn from biblical history, this last coinciding with the classical use of historical exempla of virtues and vices. But the poem is noted above all as a pioneering work of personification allegory. In this paper I shall consider two aspects of what I shall, provocatively, call Virgil's Prudentian allegorical techniques: firstly, personification allegory, with reference to the Allecto episode in Aeneid 7 and the story of Hercules and Cacus in Aeneid 8; and secondly, the allegorical and imagistic networks that proliferate from Virgil's programmatic storm in Aeneid 1.

\section{Personification allegory}

7 Under this heading I approach a comparison of Prudentius and Virgil from the angle of the relationship between personification and history. Personification allegory is sometimes perceived as inherently timeless, putting on stage abstractions detached from particular historical events. Typology, by contrast, is a form of allegory rooted in history. But a number of studies have brought out the ways in which the prevailing personification allegory of the Psychomachia is itself inseparable from the history of the Church. ${ }^{5}$ This is especially true of the first and last of the seven confrontations: Fides vs. Veterum Cultura Deorum, and Concordia vs Discordia. Time is built into the first of these meetings, which results in the death of something old, the ueteres dei, so allowing for the renewal, re-nouatio, that is at the heart of both the Christian theology and imperial ideology of late antiquity. ${ }^{6}$ Furthermore Fides, both in her own unarmed defiance of her violent persecutor, old paganism, and in the thousand martyrs who accompany her, takes us to the heroic days of the early church, the time of the martyrs, which had ended the better part of a century before the time of Prudentius' first readers. ${ }^{7}$ This host of martyrs includes the individuals whose histories form the subject of the Peristephanon. The death of Veterum Cultura Deorum is not easy or quick, 35 difficilemque obitum suspiria longa fatigant 'long gasps make a hard and difficult death': commentators refer this to the length of time it took the Christian emperors to extinguish pagan idolatry. ${ }^{8}$

8 The last of the encounters in the Psychomachia, between Concordia and Discordia, breaks out after what has seemed to be the definitive conclusion of hostilities once the other Vices have been defeated. Discordia is here the divisiveness of heresy, by which name the unmasked creature christens herself before she is torn to pieces, 709-10 'Discordia dicor, I cognomento Heresis' 'I am called Discord, my other name is Heresy'. Her treacherous assault on Concordia after the establishment of peace is a reflection of a historical situation, the emergence of heretical doctrines after the establishment of the 'peace of the Church' ${ }^{9}$ with the Edict of Milan in 313, and the ending of persecution, the ending of the 'age of martyrs'. ${ }^{10}$

9 The episodes of Fides versus Veterum cultura deorum and of Concordia versus Discordia have Virgilian models, each of which has a strongly allegorical quality, but each of which is firmly rooted in Roman history.

10 Discordia's attack on Concordia is modelled on the assault by the Fury Allecto on a number of Italian victims in book 7 of the Aeneid, in order to disrupt Latinus' wish to 
perpetuate Italy's long-standing state of peace through the concord reached with the Trojans. ${ }^{11}$ Allecto is a close relative of Ennius' Discordia, and Allecto crows to Juno that she has 'made perfect discord in the horror of war' (Aen. 7.545 en, perfecta tibi bello discordia tristi), fulfilling Juno's statement, 335 , tu potes unanimos armare in proelia fratres 'You have the power to arm for battle brothers of one mind', where un-animos is virtually synonymous with con-cordes. Allecto, as we shall see, is also the dominant Virgilian model for the vice Libido, whose confrontation with Pudicitia is the second in the series of duels in the poem. The Allecto sequence is one of the most allegorical, and least mimetically realistic, episodes in the Aeneid. But the madness visited by Allecto in Aeneid 7 is a mythical representation of historical as well as psychological realities, a foreshadowing in particular of the civil war between Pompey and Caesar. Ennius' Empedoclean Discordia had also been tied to a particular moment in Roman history, the revolt of Falerii in $241 \mathrm{BC}$.

The major Virgilian model for the first combat in the Psychomachia, between Fides and Veterum cultura deorum, comes in the following book, 8 , of the Aeneid. The fight between Hercules and Cacus is narrated by Evander on the occasion of the annual commemoration of Hercules' victory at the Ara Maxima, and is thus an event built into the Roman fasti. But this is an episode that might be seen as programmatic for a narrative manner which departs from the usual standards of mimetic realism in epic warfare, and it also combines historical and moral allegory in a way suggestive for the Psychomachia. ${ }^{12}$ Evander claims that the recently instituted worship of Hercules is not unmindful of the old gods, Aen. 8.185-8 'non haec sollemnia nobis, / has ex more dapes, hanc tanti numinis aram / uana superstitio ueterumque ignara deorum / imposuit' 'This annual rite, this set feast and this altar to a great divinity have not been imposed upon us by any vain superstition working in ignorance of our ancient gods.' At 189 meritosque nouamus honores, nouamus is ambiguous between 'renew (annually)', and 'invent, innovate with'. ${ }^{13}$ This religious aition, marking a particular 'date' in history, is the earliest point in a history of Rome, sketched out allusively and prophetically in Aeneid 8 , that includes the actual foundation of the city itself, and reaches down to the present day, to Augustus.

12 Evander's story of Hercules and Cacus tells of the victory of a new god whose worship is nevertheless accommodated within the cults of the ueteres dei. Hercules is, after all, the son of the supreme father-god Jupiter, whose awe-inspiring presence in the heart of the future Rome is revealed by Evander when he takes Aeneas on a tour of the place (Aen. 8.349-54). Hercules' divine paternity is emphasized by the Salii in their hymn, at 8.301 salue, uera Iouis proles, decus addite diuis 'Hail, true son of Jupiter, glorious accession to the gods'. However the relationship between Hercules and Jupiter, son and father, is very different from the relationship between God the Son and God the Father, whose indivisible unity is the starting-point of the main, hexameter, section of the Psychomachia (2-4). Christ was always god, whereas Hercules only became a god. Hercules' defeat of Cacus alludes to Epicurus' defeat of the personification Religio at the beginning of the De rerum natura. ${ }^{14}$ But Virgil reverses the Lucretian message, since the dira religio of Jupiter is still rooted in the soil of Rome, now as it was in the time of Evander.

13 By putting Veterum Cultura Deorum in the role of Cacus, Prudentius sets an absolute divide between the old pagan religion and the new Christian religion, in a manner that reverts to the Lucretian saviour Epicurus' uncompromising destruction of the previous 
religious regime..$^{15}$ For Prudentius Veterum Cultura Deorum is synonymous with uana superstitio, ${ }^{16}$ collapsing the opposition in Evander's claim non haec sollemnia nobis ... uana superstitio ueterumque ignara deorum / imposuit. The Lucretian inversion whereby superstitio ends up being trampled underfoot is also a model for the typical Prudentian punishment of a vice through lex talionis or as contrappasso. ${ }^{17}$ But Prudentius will instal his own, Christian, version of Super-stitio at 640-3, after the preliminary conclusion of hostilities:

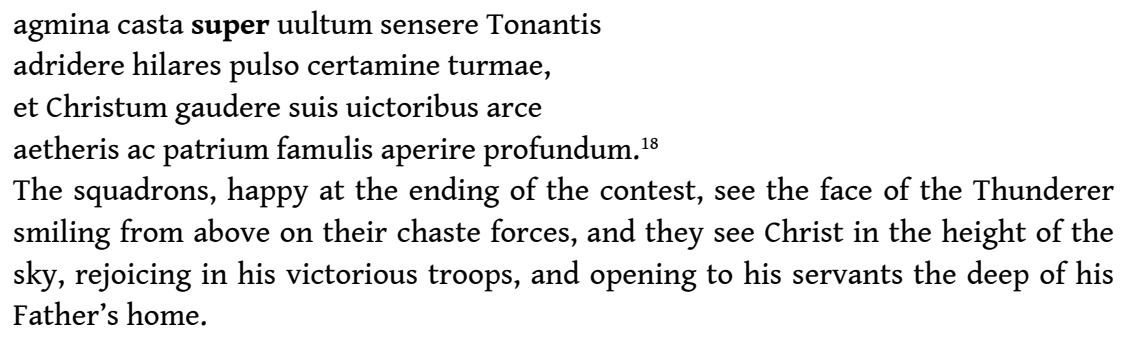

14 There are other reasons why the Hercules and Cacus episode is a privileged one for Prudentius. Freed from the constraints of mimetic realism that govern the encounters in the warfare of the primary narrative of the war in Latium, this clash between a chthonic, hellish monster and the son of the supreme Olympian, himself to become an Olympian god, comes close to being an allegorical battle. The sense of a conflict between virtue and vice is reinforced by the onomastic opposition of Ev-ander 'good man' and Cacus 'bad (man)'. The fight between Hercules and Cacus stands outside the series of single combats in the war in Latium, but at the same time it is the first such 'duel', and it also foreshadows - or prefigures - later single combats, in particular the final duel between Aeneas and Turnus in Aeneid 12, and it also foreshadows the final battle represented in book 8, the Battle of Actium, the 'last battle' of Roman history. Indeed the Hercules and Cacus story has some claim to be the most allegorical episode in the Aeneid, both as a moral allegory of a struggle between good and evil, and as an event that enters into allegorical relationships with other events, in the language of Biblical exegesis, as a 'type'. Book 8 of the Aeneid is the book to which the model of Biblical typology can most readily be applied (see below). The fight between Fides and Veterum Cultura Deorum is an allegory of the larger historical process of the confrontation of Christianity and paganism, and it is also a model for, or prefiguration of, other individual combats, between martyrs and their persecutors, unarmed and defenceless Christians whose faith allows them to be victorious over those who torture and kill them. ${ }^{19}$

15 The very brief episode of Fides and Veterum cultura deorum encapsulates the trajectory of the poem as a whole, from entrance on to the field of combat, through defeat and killing of the enemy to victory celebration. This microcosmic recapitulation is shared with the Virgilian Hercules and Cacus episode, in which (narrative of) the combat is followed by celebration of the laudes and facta of Hercules in the hymn of the Salii. This sequence in turn foreshadows the larger pattern of Roman history represented on the Shield of Aeneas, the history of Roman wars, bella, climaxing in the clash between Augustus and Antony, sketched in unrealistic and allegorizing ecphrasis, and including an image of Discordia (Aen. 8.702), followed by a scene of triumph and a newly built temple.

16 The second Prudentian combat, between Pudicitia and Libido, ${ }^{20}$ like the final encounter between Concordia and Discordia, activates another focal point of Virgilian allegory, or 
what might perhaps be labelled 'proto-allegory', the figure of the Fury. Libido is first anchored in a biblical context, introduced as (42) patrias succincta faces Sodomita Libido 'Lust the Sodomite, girt with the firebrands of her fatherland', and is then identified as a monster from the classical world, labelled (46-7) Furiae flagrantis 'blazing Fury' and dirae | ... lupae 'dire whore'. Here the reader might take Dirae as a noun, synonymous with Furiae, until we read on to the next line and realise that it is an adjective. After killing Libido, Pudicitia addresses her as (96) furiarum maxima (= Aen. 3.252, 6.605), and sends her packing to Hell, there to roll in waves of fire and sulphur forever, condign punishment for one whose weapons are the sulphurous torches of lust. This is a Christian rewriting of the destination of Virgil's Allecto, who returns to the infernal shadows of the Underworld whence she came, after infuriating the inhabitants of the world above. There are two differences: Libido's point of origin is in the world of men, as a citizen of Sodom (with 42 patrias succincta faces Sodomita Libido contrast Aen. 7.324-5 luctificam Allecto dirarum ab sede dearum / infernisque ciet tenebris '(Juno) rouses Allecto, bringer of grief, from the home of the dread goddesses and the darkness of the underworld'), and she goes to Hell to suffer the torments that the pagan Fury inflicts on others.

Libido's mode of operation is that of the Virgilian Allecto and of Allecto's human victims. With 43-5 piceamque ardenti sulpure pinum / ingerit in faciem pudibundaque lumina flammis | appetit, et taetro temptat subfundere fumo 'she thrusts into Chastity's face a pine torch blazing with pitch, attacking her modest eyes with the flames and trying to cover them with foul smoke', compare Aen. 7.456-7 (Allecto attacking Turnus) sic effata facem iuneni coniecit et atro / lumine fumantis fixit sub pectore taedas 'With these words she threw a burning torch at the warrior and fixed it in his breast, smoking with black light', and 9.71-2 (Turnus attacking the Trojan ships) sociosque incendia poscit ouantis / atque manum pinu flagranti feruidus implet 'he demanded fire from his exultant comrades, and ablaze with fury he took up a burning torch in his hand'. Virgil's Allecto is a full mythological person, but she comes close to being a personification of furor, furia, with a small $f$. That is one reason why Allecto is an important model for two of the four major personification allegories in Ovid's Metamorphoses, Inuidia and Fames. Another reason is that her mode of operation, which is to transform her victims into versions of herself, makes of her an agent of metamorphosis. ${ }^{21}$ And for Prudentius this quality of Allecto and of the results of her interference in the world of human kind is a kind of licence for the slippage from a narrative whose characters are fully human beings to a narrative of the deeds of personifications.

This can be seen working in the opposite direction in the case of Prudentian Vices whose actions are modelled on those of fully human characters in the classical epic tradition, but humans acting in the grip of a ruling passion. Ira's breaking of her sword on the invulnerable helmet of Patientia is modelled on the scene near the end of Aeneid 12 where Turnus' sword shatters on the divinely-made armour of Aeneas (12.728-45). Turnus is one of the victims of the Fury Allecto, the near-personification of furor who inspires in Turnus an angry furor that makes of him a hypertrophied specimen of the angry epic hero: ira caps the catalogue of infuriated emotions which erupt in Turnus' breast after Allecto thrusts her smoking torches into it, Aen. 7.460-2 arma amens fremit, arma toro tectisque requirit; / saeuit amor ferri et scelerata insania belli, / ira super 'In his frenzy he roared for his arms, he looks for his arms in his bed and in the palace; lust for iron raged within him, and a criminal madness of war, and, in addition, anger'. This is followed by the simile of a cauldron boiling over which alludes to a Lucretian 
description of lions as the embodiment of ira (DRN 3.294-8). One might say that, once he has been infected by the Fury, Turnus tends to the status of a human embodiment, or personification, of furor and ira. At the same time he is, of course, a more complex and rounded character than is a personification. His response to his shattered sword in Aeneid 12 is to panic and flee. The reaction of Ira, who cannot act other than as a personification of anger, is to turn her anger against herself (150 ad proprium succenditur effera letum 'her savagery fires her to kill herself'). This is the response of another obsessively angry hero, the Ovidian Ajax, whose response to his worsting in the judgement over the arms of Achilles is to direct his anger against himself, Met. 13.384-5 Hectora qui solus, qui ferrum ignesque Ionemque / sustinuit totiens, unam non sustinet iram 'anger was the only thing that Hector, the man who so often single-handedly withstood weapons, fire and Jupiter, could not withstand.'. In the Ira episode Prudentius also alludes to the archetypal epic angry hero, Achilles, via an intertextual memory of Horace's characterization of the angry Iliadic Achilles, applied however not to Ira but to her opponent Patientia's helmet: with 143-4 dum cedere nescia cassos / excipit adsultus ferienti et tuta resistit 'the steel that could not yield receives the vain attack, and stands up to the striker without hurt', compare Horace Odes 1.6.5-6 grauem / Pelidae stomachum cedere nescii 'the oppressive anger of Achilles, who could not yield'. The Ovidian quote shows that the unrestrainable anger of one angry hero, Ajax, does have its weak point, itself, and to that it does yield.

\section{The programmatic storm}

19 I turn now to the allegories generated by the programmatic storm in Aeneid 1. The divine, the natural, and the human political worlds are drawn into a mutually implicative network of signification. The interaction between microcosm and macrocosm, between individual psychology and the workings of the state, is engineered through a furor that is both the expression of the psychology of an individual, here a goddess, Juno, but a goddess behaving in a very anthropomorphic way, and also the motive force for the disruption of a polity, in the shape of the seditio that threatens the cohesion of the Roman state in the statesman simile. There the word furor appears for the first time in the poem in a quasi-personification, 1.150 iamque faces et saxa uolant, furor arma ministrat 'and now torches and rocks were flying, fury supplies weapons', to be followed by the full-blown personification of Furor at the word's second appearance at the end of the Speech of Jupiter, in the image of Furor bound, 294-6 Furor impius intus ... Aeolus' royal control of the 'people' of the winds is also a psychotherapy, 57 sceptra tenens mollitque animos et temperat iras 'holding his sceptre he calms their spirits and moderates their anger', with the pun on animus ö $v \varepsilon \mu o r$ 'winds'.

The analogy of soul and state (Church) is central to the Psychomachia. Kurt Smolak sees this as a Platonic analogy. ${ }^{22}$ However, the analogy is first introduced through Virgilian allusion in Prudentius' opening prayer to Christ, 5-11:

dissere, rex noster, quo milite pellere culpas

mens armata queat nostri de pectoris antro, ${ }^{23}$

exoritur quotiens turbatis sensibus intus

seditio atque animam ${ }^{24}$ morborum rixa fatigat,

quod tunc praesidium pro libertate tuenda

quaeue acies furiis inter praecordia ${ }^{25}$ mixtis

obsistat meliore manu. 
Tell us, our king, with what soldiery our mind is armed and enabled to expel the sins from the cavity of our breast, whenever our senses are in turmoil and rebellion arises in us, and the strife of our diseased passions wears out our spirit - say what help there is then to guard our liberty, what army can resist with superior force the furies combined in our heart.

seditio, the word used by Virgil of the civil disturbance in the statesman simile, the first simile in the poem, suggests that the battle of the soul is like a conflict within a political body. The singular mens armata (6) becomes an army, acies, in line 10, arrayed against the $f / F u r i a e$ (the third equivalent for 'Vices', after 5 culpas, 8 morborum, before the introduction of the word Vitia itself at line 13, after Virtutum at the same place in the line before). seditio also looks forward to the climactic 'civil war' of heresy within the Church, embodied in Discordia's underhand assault on Concordia at $665 \mathrm{ff}$.

That is after what had seemed the conclusive end of the war, the establishment of Pax, and the return to camp under the leadership of Concordia. ${ }^{26}$ That point in the poem is marked by further Virgilian allusion, and by the first - and only proper - simile in Prudentius' epic (so perhaps having something of the privileged status of the first simile in the Aeneid). The simile compares the victory song of the Virtues to the song sung by Moses and the children of Israel after the crossing of the Red Sea (Exodus 15:1-21). The Biblical historical event is 'post-figured' ${ }^{27}$ in the victory of the soul. The crossing of the Red Sea and the drowning of the Egyptians uses the language of the storm: 650-1 hiantem / ... rabiem ponti post terga minacis 'the yawning gulf of the sea that raged menacingly behind them', 653-5 stridensque per extima calcis / mons rueret pendentis aquae nigrosque relapso / gurgite Nilicolas fundo deprenderet imo 'the hanging mountain of water crashed down hissing at the tips of their heels, and the flood falling back caught in its depths the black-skinned people of the Nile': compare Aeneid 1.105-7 insequitur cumulo praeruptus aquae mons. / hi summo in fluctu pendent; his unda dehiscens / terram inter fluctus aperit 'There came towering over them a sheer mountain of water. Some of the ships were hanging on the crests of the waves; for others the waters opened and revealed land amidst the waves'. ${ }^{28}$ The combination of triumphal celebration in newly bright weather, ${ }^{29}$ after a victory allusively compared to a storm repeats the combination on the Shield of Aeneas of a final battle that alludes, in a ring, to the storm at the beginning of book one,$^{30}$ with the scene of triumph, watched by Augustus from the gleaming temple of the sun-god Apollo.

The linguistic figure of simile introduces an event in Old Testament history, Exodus and the crossing of the Red Sea, that was a particular focus for typological exegesis, beginning with Paul's interpretation of it as a figure for baptism. ${ }^{31}$ Moses is a figure for Christ, Egypt a figure for the world, and Pharaoh a figure for Satan who rules the world. The entry into the Promised Land also prefigures the Christian soul's entry into Paradise, as in Prudentius' generalization of the story of Exodus to a message about God's guidance of his people at Cathemerinon 5.109-12 fessos ille uocat per freta saeculi I discissis populum turbinibus regens, / iactatasque animas mille laboribus / iustorum in patriam scandere praecipit 'He calls the weary across the world's sea, guiding his people, cutting through the storms, souls tossed about by countless struggles - he bids them climb to the homeland of the just' (transl. Richardson). These lines combine a reprise of the crossing of the Red Sea (note in particular discissis, hinting at the division of the Red Sea) with the language of the Virgilian storm-tossed hero (iactatas, laboribus). A similar combination of Virgilian and biblical is found in the description of Christ's joy in the victory of his troops, and invitation to the celestial homeland, at Psych. 642-3 et 
Christum gaudere suis uictoribus arce / aetheris ac patrium famulis aperire profundum. The choice of profundum to refer to the heights of heaven anticipates the opening of the depths of the Red Sea in the simile a few lines later; patrium ... aperire alludes to the opening of the heavens above Augustus in the description of the battle of Actium at Aen. 8.681, revealing Augustus' father in heaven, Julius Caesar in the form of the Julian Star, patriumque aperitur uertice sidus. ${ }^{32}$

These interweavings of biblical and Virgilian at the detailed verbal level are symptomatic of a larger symbiosis between Prudentian and Virgilian signifying practices. A number of scholars in the last century found in the typology of biblical exegesis a useful model for thinking about the allegory and symbolism of the Aeneid. Prudentius had got there before, with his easy combination of typology with Virgilian allusion. The allegory of the Psychomachia cannot of course be properly understood without an awareness of biblical, Pauline and patristic ${ }^{33}$ sources and interpretative practices, but these are integrated with a Prudentian reading of the Aeneid. ${ }^{34}$ But reading the Aeneid through the Psychomachia may also make us see Virgil's epic in a somewhat different light, as being open to a reading that is profoundly and sustainedly allegorical.

\section{BIBLIOGRAPHY}

Buchheit, V. 'Glaube gegen Götzendienst (Prud. psych. 21 ff.)', RhM 133 (1990) 389-96

Cameron, Averil 'Constantine and the peace of the church', in M. M. Mitchell and F. M. Young (eds.) The Cambridge History of Christianity. Origins to Constantine (Cambridge 2008) ch. 30

Cavarzere, A. Sul limitare. Il 'motto' e la poesia di Orazio (Bologna 1996)

Charlet, J. L. 'La tempête apaisée et la marche sur l'eau dans la poésie de Prudence', Studi tardoantichi 7 (1989) 227-47

Corsano, M 'Sul secondo combattimento della Psychomachia di Prudenzio', in A. M. Taragna (ed.) La poesia tardoantica e medievale (Alessandria 2004) 95-107

Deproost, P. A. 'L'intériorisation des espaces épiques dans la Psychomachie de Prudence', in E. Leonardy and H. Roland (eds.) Descriptions et créations d'espaces dans la littérature (Louvain-laNeuve 1995) 53-75

Gildenhard, I. 'Confronting the beast - from Virgil's Cacus to the dragons of Cornelis van Haarlem', Proc. Virgil Soc. 25 (2004) 27-48

Gnilka, Christian Studien zur Psychomachie des Prudentius (Wiesbaden 1963)

Gnilka, Christian Prudentiana II. Exegetica (Munich and Leipzig 2001)

Gnilka, C. 'Verschiedenes zu Prudentius', in Philologische Streifzüge durch die römische Dichtung (Basel 2007) 403-40

Gnilka, C. 'Die Bedeutung der Psychomachie im Gesamtwerk des Prudentius', in B. Jakobs and V. Kapp (eds.) Seelengespräche (Berlin 2008) 19-39 
Hardie, P. Virgil's Aeneid: cosmos and imperium (Oxford 1986)

Hardie, P. Ovid's poetics of illusion (Cambridge 2002)

Hardie, P. Lucretian receptions. History, the sublime, knowledge (Cambridge 2009)

Ludwig, W. 'Die christliche Dichtung des Prudentius und die Transformation der klassischen Gattungen', in M. Fuhrmann (ed.) Christianisme et formes littéraires de l'antiquité tardive en Occident (Geneva 1977) 303-63

Lühken, M. Christianorum Maro et Flaccus: zur Vergil- und Horazrezeption des Prudentius (Göttingen 2002)

Magazzù, Cesare 'L'utilizzazione allegorica di Virgilio nella Psychomachia di Prudenzio', BSL 5 (1975) 13-23

Mahoney, A. Vergil in the works of Prudentius (Washington 1934)

Mastrangelo, M. The Roman self in late antiquity. Prudentius and the poetics of the soul (Baltimore 2008)

Roberts, A. J. The Red Sea crossing and Christian baptism. A study in typology and liturgy (PhD Durham 2014)

Rohmann, D. 'Das langsame Sterben der Veterum Cultura Deorum', Hermes 131 (2003) 235-53

Roston, M. Biblical drama in England from the Middle Ages to the present day (London 1968)

Schmidt, E. A. 'Problematische Gewalt in der Psychomachia des Prudentius?', in V. Panagl (ed.)

Dulce melos. La poesia tardoantica e medievale. Atti del III Convegno internazionale di studi (Vienna, 15-18 novembre 2004) (Alessandria 2007) 31-51

Schwen, C. Vergil bei Prudentius (diss. Leipzig 1937)

Shanzer, Danuta 'Allegory and reality: Spes, Victoria and the date of Prudentius' Psychomachia', ICS 14 (1989) 347-63

Smolak, K. 'Die Psychomachie des Prudentius als historisches Epos', in M. Salvadore (ed.) La poesia tardoantica e medievale (Alessandria 2001) 125-48

Thraede, K. 'Concordia Romana in der Antwort des Prudentius auf die 3. Relatio des Symmachus', in Tesserae (Festschr. f. J. Engemann) (Münster 1991) 380-94

\section{NOTES}

1. Prudentius and Virgil: Mahoney 1934, Schwen 1937, Lühken 2002.

2. Magazzù 1975: 15 compares this ostentatious referencing of a Virgilian line to the Horatian use of a 'motto', a close adaptation of a Greek lyric model, in the opening words of an ode (on which see Cavarzere 1996). However it is unlikely that Prudentius, despite being as careful a student of Horace as he was of Virgil, would have been aware of Horace's Greek models.

3. See Gnilka 2001: 58-61 for a subtle and penetrating discussion of Prudentius' revalorization of the Virgilian line. Gnilka notes the adaptation of the same Virgilian line by Paulinus of Nola, Carm. 18.260 (the cowherd seeking the return of his oxen) Felix sancte meos semper miserate labores.

4. The Psychomachia opens with a request for instruction, 5-6 dissere, rex noster, quo milite pellere culpas / mens armata queat nostri de pectoris antro: cf. Lucretius' use of dissero in setting out his didactic programme at De rerum natura 1.54-5 nam tibi de summa caeli ratione deumque / disserere incipiam et rerum primordia pandam; 6.940; for the indirect didactic question introduced by quo cf. 
the indirect questions that open the Georgics, 1.1-5 Quid faciat laetas segetes, quo sidere terram I uertere, etc. With quo milite epic military subject-matter is diverted to didactic ends. The militarydidactic function of the Psychomachia has already been signalled in the Praefatio 6-10 docens ad aram cum litare quis uelit ... pugnare nosmet cum profanis gentibus / suasit. The closing thanksgiving to Christ addresses him as a teacher, 888-9 reddimus aeternas, indulgentissime doctor, I grates, Christe, tibi. On the importance of Lucretius as a model for the Psychomachia see Smolak 2001.

5. Shanzer 1989; Deproost 1995, reading the Psychomachia as the product of a privileged moment of the Theodosian empire; Smolak 1998; Schmidt 2007. Gnilka 2008: 31 identifies the interpenetration of history with the battle in the soul as a challenge for the exegete of the Psychomachia: 'Das große Thema der Psychomachie ist ... die triumphale Überwindung der alten Sündenwelt durch die sittlichen Kräfte der neuen Religion.'

6. There is perhaps a doubletake, of an Ovidian kind, in 24-5 namque repentinus laudis calor ad noua feruens / proelia, where ad noua feruens could be taken as ablaze for the new things [of Christianity]' before we read on to proelia. noua proelia itself can be taken in two ways, 'fresh contests', further to those fought by Fides in the past, and 'novel' in that hers is a mode of combat alien to the conventions of traditional epic.

7. Buchheit 1990.

8. Rohmann 2003.

9. On the 'Peace of the Church' see Cameron 2008.

10. The structure of the Psychomachia is reflected in the structure of the hexameter component of Prudentius' ceuvre: preceding the Psychomachia come two poems which combat heresy, the Apotheosis and the Hamartigenia, following are the two books of Contra Symmachum, attacking paganism: see Ludwig 1977.

11. Aen. 7.46 (Latinus) iam senior longa placidas in pace regebat; $284-5$ talibus Aeneadae donis dictisque Latini | sublimes in equis redeunt pacemque reportant.

12. Prudentius inverts the order of the Allecto and Hercules and Cacus episodes in his imitations. The two Virgilian episodes were particularly adaptable to Christian narratives: Allecto as an allegory for original sin, the serpent in the garden; and Hercules' defeat of the chthonic Cacus as foreshadowing Christ's Harrowing of Hell.

13. See Henry ad loc. who sides with Wagner, against Heyne and Peerlkamp, in understanding 'Facimus haec et insolita sacra'; 'Neque excusatione opus esset Evandro, si non esset noua atque insolita haec superstitio.'

14. See Hardie 2009: 171-2, referring to Gildenhard 2004.

15. Smolak 2001: 128-9, in the context of Lucretian models for Prudentius, notes the parallel between the replacement of Apollo by Christ in the first line of Psychom. and the replacement of Hercules by Epicurus in the proem to DRN 5 .

16. uana superstitio is used elsewhere by Prudentius at Apoth. 510 (in the context of Christ's conquest of simulacra deum Tarpeia), and Symm. 1.198; cf. also Symm. 1.39 utque superstitio ueterum procul absit auorum.

17. Gnilka 1963: ch. 3.

18. Cf. Lucr. 1.65 (the unsmiling face of Religio) horribili super aspectu mortalibus instans; Prudentius' choice of the pagan Tonans to refer to the Christian supreme god reminds us that fulmina inspire the religious dread from which Epicurus frees mankind (DRN 1.68-9). But the new, Christian, sky religion welcomes mankind to the heavens, rather than keeping it in oppression on earth: DRN 1.79 nos exaequat uictoria caelo is indeed the message of the Psychomachia.

19. See Buchheit 1990: 391 on the parallel with Perist. 2.2 ff. Laurence's victory over barbarous pagan cult, through Fides.

20. See Corsano 2004.

21. Hardie 2002: 233-4.

22. Smolak 2001. One might ask if the analogy in Virgil is itself Platonic, perhaps via Cicero. 
23. Aen. 1.52 uasto rex Aeolus antro; 60 sed pater omnipotens speluncis abdidit atris.

24. Aen. 1.57 mollitque animos et temperat iras.

25. Aen. 7.347 praecordia ad intima subdit.

26. For the analogy between the bringing of peace in the wider world and in the human breast cf. Symm. 2.619-33, the triumphs of Rome prepare the way for the coming of Christ, with peace in the world and in human breasts, 623-5 nam locus esse Deo quis posset in orbe feroci / pectoribusque hominum discordibus et sua iura / dissimili ratione tuentibus ..?, with the further analogy between order in the soul and in the state at 629 at si mentis apex regnandi iure potitus ... (discussed by Deproost 1995: $74 \mathrm{ff}$.).

27. I use the term of Roston 1968.

28. Cf. also the allusions to the Virgilian storm in Prudentius' account of the drowning of the Egyptians at Cath. 5.77-9 currus tunc et equos telaque naufraga / ipsos et proceres et uaga corpora / nigrorum uideas nare satellitum: cf. Aen. 1.118-19. On Prudentius' use of classical epic storms in his several verse renderings of Jesus' calming of the storm see Charlet 1989.

29. 638-9 suda redit facies liquidae sine nube diei, I purpuream uideas caeli clarescere lucem.

30. See Hardie 1986: 102-4 on the imagery of Gigantomachic convulsion that links storm and Actium.

31. 1 Cor. 10:1-2 nolo enim vos ignorare fratres, quoniam patres nostri omnes sub nube fuerunt et omnes mare transierunt. et omnes in Mose baptizati sunt in nube et in mari. Cf. Psych. 89 ff. Pudicitia plunges Libido in the fiery waters of Underworld, and then washes her sword in waters of Jordan, abolens baptismate labem / hostilis iuguli. See Roberts 2014.

32. On the Lucretian allusions in these lines see above.

33. Gnilka 2007: 377 'Prudentius muß aus den Vätern erklärt werden.'

34. At a general level this is consistent with the line followed by Mastrangelo 2008 in his reading of Prudentius, e.g. 81 '(Prudentius') literary achievement rivals the political and historical sophistication of the Aeneid, which helped shape Roman identity for centuries.'

\section{ABSTRACTS}

This essay focuses on the feature of the Psychomachia that is supposed to mark a decisive break from the tradition of classical epic, the fact that it is an allegorical epic, and ask how Virgilian, in reality, its allegorical themes and procedures may be. As a study of intertextuality, the paper further poses the question of whether reading the Psychomachia through the Aeneid also brings yields in terms of reading the Aeneid through the Psychomachia. In particular I consider two aspects of what I shall, provocatively, call Virgil's Prudentian allegorical techniques: firstly, personification allegory, with reference to the Allecto episode in Aeneid 7 and the story of Hercules and Cacus in Aeneid 8; and secondly, the allegorical and imagistic networks that proliferate from Virgil's programmatic storm in Aeneid 1.

\section{INDEX}

Keywords: Prudentius, Virgil, allegory, personifications, typology, virtues, vices, storm 
AUTHOR

PHILIP HARDIE

Trinity College, Cambridge 